\title{
HOPE AS THE PROVISION FOR PSYCHOLOGICAL SECURITY OF THE PERSON AND THE SOCIETY1
}

\begin{abstract}
The article discusses various approaches to understanding the function of hope in human life. The author attempts to analyze the functional orientation of hope based on its types. The rationale for the study of hope as a multidimensional formation in the context of human life and person's attitude to life is presented. The paper analyzes the conception of hope among Russians, discusses the relationship between different types of hope and valence (positive-negative) of evaluations of different stages of one's life course. It is emphasized that high level of hopelessness combined with negative attitude towards life reduces the psychological security of a person.

Keywords: ontological functions of hope, components of hope, emotional type of hope, cognitive-motivational-behavioral type of hope, scope and objects of hope, attitude to life.

\section{Introduction}

Traditionally, issues of psychological security are considered in the context of countering destructive, extremist influences on a person. In our opinion, the problem of psychological security of the individual and society can be posed more broadly, affecting various aspects of everyday life, which may not always be classified as extreme or extremist, but have a significant influence on a person resulting in their psychological humiliation and even destruction. Such situations of everyday life can include both situations of loss of hope or hopelessness and situations overflowing with hopes. It all depends on what types of hope we mean, in what direction they regulate the behavior of a person and determine his choice in situations that threaten his life and his psychological well-being. Theoretical conclusions that hope is a universal, global and common human phenomenon that gives meaning to life can be considered sufficient for understanding and recognizing the regulating power of hope (Chalikova, V. A. ,1991), (Bol'nov, O. F.,

\footnotetext{
${ }^{1}$ This article is being reprinted at the request of the author. The article was first published in Russian in December 2011. Available at:

https://www.researchgate.net/publication/292130115 Hope as the Provision for Psychological Security of the Person and the Society
} 
2001), (Vershinin S. E., 2000), (Kleman, O.,1994). Similarly, these conclusions require comprehension from the point of social psychology, taking into account the course of life of the individual and society, prevailing ethno-cultural values, the degree of positivitynegativity of assessments of life events, attitude to life, conception of the functions of hope and its types among the Russians.

Thus, the purpose of this article is to consider the phenomenon of hope from the point of social psychology and demonstrate its ambiguous connection with the practical psychology of security of an individual and society.

There are various definitions of hope and its functions in the history of philosophy, religion and psychology. They are presented in sufficient detail in a number of works (Chalikova, V. A., 1991), (Vershinin, S. E., 2000), (Kapiton, V. P., 1992) (Mansurova I. S., 2005), (Muzdybaev, K.,1999) as well as discussions about the functions of hope in a person's life: "Is hope evil or good?" Two main interpretations of the meaning of hope in human life have been preserved in physics, philosophical and psychological literature so far. The most significant concepts, emphasizing the existential, ontological meaning of hope are those in which the latter is endowed with viable power and acts as the foundation of human existence; it is also endowed with the function of opposition to entity (Chalikova, V. A.,1991), (Bol'nov, O. F., 2001), (K'erkegor, S.,1993), (Sartr, Zh. P.,1989), (Fromm, E., 2005). In a concentrated form, this semantic orientation of hope is presented in S. E. Vershinin "Life is hope" (Vershinin, S. E., 2000).

Most often, the problem of hope in connection with the different historical upheavals and generalizing negative assessments of human life, disappointment and fear is raised in literature. For modern society, as noted by O. F. Bolnov, the disappearance of the "romantic spirit", provoked by a huge number of upheavals, is characteristic. As a result, "every life relationship", "every life meaning" turned out to be illusory. "And the world with a previously unknown threat acted in relation to man as strange and dangerous .... The man realized himself in a certain hopeless loss, doomed to the destruction penetrating into him ...." (Bol'nov, O. F., 2001, p. 139). Such phenomena as fear, despair, boredom and disgust become "carriers of the decisive metaphysical experience" and hope in the state of entity fulfills the function of overcoming. Developing this idea, O. F. Bolnov emphasizes that it is mainly hope that "is put forward as the only condition for realization of human life" (Bol'nov, O. F., 2001, p. 141). In such interpretations, hope is associated with faith and trust in entity and is interpreted as trust in the future; the presence of hope in a person's life and attitude towards it as a value is considered as a "connection" between a person and entity (Bol'nov, O. F., 2001, p. 143). 
A special place in understanding the existential role of hope is presented in the work of E. Bloch (Chalikova, V. A.,1991). He builds his reasoning on the basis of a new model of a person, a "hopeful" person. Hope is attributed to an anti-romantic, that is, practical nature. In other words, a practical hope is opposed to probable-passive hope, irrational hope to rational, conscious hope to unconscious one. The diversity of hopes is associated with the richness of human existence and experience. E. Fromm (Fromm, E., 2005) speaks about hope in his work, pointing out that hope is the absolute value of the future, emphasizing that hope is an indicator of state of entity, "the moment of life structure". He endowed hope with the function of transforming being, its change in the direction of greater vitality, awareness, etc. (Fromm, E., 2005, p. 305). At the same time, E. Fromm believed that hope has the property of paradox, noting that it is"... neither passive expectation nor an urge of circumstances that cannot be realized" (Fromm, E., 2005, p. 302); he pointed to the existence of a special type of hope - "passive hope", which is a disguised form of hopelessness.

Consequently, the attitude towards hope itself and the assessment of the temporal stages of a person's life can actualize such a function of hope as the "connection" of a person with his existence, the transformation of existence and can assign other functions to hope, depending on its type. In this regard, no less important in comprehension of hope, from a socio-psychological point of view, are the concepts which assert that hope is a life-limiting power, self-deception that prolongs the torment of people, a "brake" of personal growth, slowing down or making the process of self-development and selfimprovement impossible (Kamyu, A.,1990), (Nicshe, F.,1990) (Shopengauer A.,1992). K. Muzdybaev (Muzdybaev, K. ,1999), speaks about possible dysfunctions of hope, especially illusory, mystical, revolutionary and messianic, therefore, it is necessary to remember that there are various types of hope and criteria for their allocation. So, in connection with the phenomenon of "loss of hope", such types as "common hope" and "fundamental hope" are discussed, which is considered as "personal existence, virtue, an expression of consent with oneself that constitutes existence" (quoted in (Bol'nov, O. F., 2001, p. 140).

The prevailing ideas about hope include various components of hope, thus giving it a certain definition: 1) hope is an emotional state, passion; 2) hope is a rationalepistemological attitude to values, striving to comprehend existence. In these definitions, the cognitive component of hope is strengthened, bringing it closer to such a form as "rational hope"; 3) hope is the planning of human activities and overcoming barriers and obstacles on the way to achieving the goal (the motivational and behavioral component 
of hope is strengthened) (Vershinin, S. E., 2000), (Gorbatkov, A. A., 2003), (Kapiton, V. P.,1992), (Muzdybaev, K.,1999), (Snyder C. R.,1994). The ontological approach to hope integrates all its components, making us consider it "as a systemic spiritual quality, representing simultaneously the sensual, rational and activity aspects of a person's attitude to the world" (Andrusenko V. A.,1999), p. 23).

In addition to the above-mentioned approaches to considering hope and its functions in human life, there are also those in which hope and despair are viewed as two interconnected and equal ways to the true existence of a person, to the transformation of his life (Bol'nov, O. F.,2001), (Kamyu, A., 1990), (K'erkegor, S.,1993), (Tillih P.,1994).

Thus, analyzing hope in the context of the psychology of the security of an individual and society, one can outline several vectors for the interpretation of its functions in a person's life. If we do not touch upon the religious interpretations of the meaning of hope and take into account their moral and ethical potential, the function of "otherness" attributed to hope (Kleman, O., (1994), p. 29), then one of the most important directions becomes the consideration of hope as a universal human value, contributing to overcoming difficulties; another is to define the type of hope and endow it with lifeaffirming or life-preventing functions.

The problem of the social psychology of hope, which is at the same time the problem of the psychology of security of the individual and society, is that it constantly emphasizes the importance of hope in the life of people, its ontological status; it examines the question of how Russians (or other nations) relate to hope, what is its value and significance in modern human interaction with the world. The statement in the philosophical and psychological works of diametrically opposite functions of hope in human life sets the task of studying the ideas about hope and its functions in a modern person, living in a situation of permanent socio-economic crisis, threats and challenges. The formulation of this problem is also due to the need for empirical verification of ideas about hope and its functions among people living in a society of "stable instability", asserting the basis of the study of existential-oriented philosophers that in a situation of experiencing alienation, fear, hopelessness, in crisis and life-threatening situations, hope helps a person to survive. As E. Fromm wrote, in extreme situations, hope determines their perception as a challenge, and not as a threat. Based on this perception, a person begins a creative comprehension of their existence and strives to overcome difficulties (Fromm, E., 2005).

In addition, in order to formulate the problem of ideas about hope and its functions in human life, the conclusions of works are important, in which hope is stated as one of the most constant features of the national character of Russians (Sikevich, Z. V.,1999), 
(Fond "obshestvennoe mnenie". Rossiiskoe obshestvo: cennosti i prioritety // Politicheskie issledovaniya (Public Opinion Foundation. Russian Society: Values and Priorities // Political Studies),1993), that along with temporary openness, activity, rejection of capitulation, belief in reality, patience is an essential characteristic of hope (Muzdybaev, K.,1999).

In order to study common ideas about hope and its functions in human life, we carried out research with 400 participants. Using the methodology "Representation of hope and attitude to it", developed by I.S. Mansurova (Mansurova, I. S., 2006), we obtained data on the prevailing types of hope, its functions in the ideas of the research participants. In order to reduce the influence of the questions posed by the researcher on the respondents' answers, the following methodological techniques were applied: associations, unfinished sentences and free definitions. The participants were asked to list all the associations that the word "hope" evokes in them; name the phenomena opposite to hope; indicate what role hope plays in a person's life and its necessity; determine how a person evaluates his life, if he hopes or has no hope. The participants were asked to state what gives them hope most of all and what can deprive them of hope; think about what they hope for in different areas of life (at work, at the institute, at home, in the family, in relations with people, etc.); make a list of hopes by completing the sentence "I hope .."; to recall and describe situations, events that inspired hope, met expectations, opened up new perspectives; remember and describe the events that led to the experience of intense disappointment, instilled a sense of hopelessness.

All the answers of the research participants were subjected to content analysis and divided into the following categories: the significance of hope in a person's life (functions), characteristics of hope (definitions), leading spheres (objects) of hope. Qualitative and quantitative analysis (frequency analysis and the procedure for categorizing the content units that form each category) showed that all respondents (regardless of their age, social status) have an idea of what hope (definition) is, what role it plays in a person's life (functions), in what spheres of life and what they hope for. Common ideas of hope include its definitions as a state, expectation and attitude to life. Most of the research participants identify hope with life, attaching the meaning of an "inner core," the meaning of life and believe that hope is something that cannot be taken away from a person. According to the research participants, hope is associated with the presence of an obstacle on the way to the goal or with a difficult life situation. But only about $30 \%$ of them associate hope with their own transformative activity aimed at achieving goals.

Interestingly, only a third of the research participants endow hope with ambivalent 
functions: "hope sometimes helps to survive, sometimes it interferes with life, increases pain when it does not come true". Emphasizing the ambivalence of the functions of hope, some participants pointed out that one should not hope for something or someone, but be responsible for one's life, rely on experience and reason. In common ideas about hope, its motivational and behavioral component is practically not reflected, but a function of hope as overcoming difficulties is mentioned.

Common ideas of hope include spheres and "objects" of hope, among which the majority ( $80 \%$ of respondents) hope for support in interpersonal interaction; they hope for understanding, being loved and respected. On the other hand, $20 \%$ of the research participants, in addition to hope for positive interpersonal relationships, point to importance of hope in the professional sphere. They hope that they will be able to realize themselves, be promoted and achieve success.

Thus, research participants associate hope with positive functions and interpersonal relations. The emphasis on the emotional and cognitive functions of hope and the reduction of the motivational-regulatory function of hope indicate a shift towards such a type of hope as "emotional", "passive" hope. Therefore, in life-threatening situations, a person will hope that acquaintances, friends will help him overcome difficulties, will protect him, while demonstrating, most often, "passive" hope, leading to disappointment and negative emotions that reduce psychological personal security. Researchers (Kamyu, A., 1990), (Muzdybaev, K., 1999), (Sartr, Zh. P.,1989), (Fromm, E., 2005) considering various types and functions of hope, emphasize that a person should have confidence in achieving his goals, he should be able to assess past successes and predict the future, move systematically towards the intended goals, to overcome difficulties, to control and manage the circumstances of their own life, to be ready for action, to transform reality. The core of "active hope" is an orientation towards the future, coupled with the transformative activity of the subject, aimed at a positively significant object for the personality, which is absent at the present time, but the achievement of which has a certain degree of probability.

In order to determine the prevailing types of hope (passive-active, emotionalrational), not in the perceptions of respondents, but on the basis of psycho-diagnostic procedures, we applied a set of methods created by I. S. Mansurova (Mansurova I. S., 2005) and reflecting our ideas about hope as a complex socio-psychological, spiritualmental-emotional education, including an emotional, cognitive and motivationalbehavioral components. This set included A. Beck's hopelessness scale (modified by A. Gorbatkov (Gorbatkov, A. A., 2003)); S. Snyder's dispositional hope scale (Snyder C. R., 
1994); A Rean's questionnaire for the diagnosis of hope for success and fear of failure. As an indicator of hope as a personal control of time, we used the index "personal control of time" from J. Newten's scale (modified by K. Muzdybaev) (Muzdybaev, K.,1999). All these techniques were aimed at diagnosing the severity of the components that constitute hope (Labunskaya V. A., Mansurova I. S., 2004). As methods aimed at studying the attitude towards life (perception and assessment of the past, present, future and life satisfaction), we applied the scale of attitudes to the time of J. Newten (as modified by K. Muzdybaev) and the questionnaire "Index of life satisfaction", adapted by NV Panina.

In order to identify the relationship between the indicators of severity of the emotional component of hope and the cognitive, motivational-behavioral one, a correlation analysis of empirical correlates and then a factor analysis by the method of isolating the main components were carried out. As a result of Varimax rotation, two factors explaining $73 \%$ of the variance were extracted. The first factor with a large factorial weight included various indicators of the severity of the motivational-behavioral component of hope ("persistence in achieving a goal", "the ability to find ways to achieve a goal", "striving to achieve", "personal control of time") and a cognitive component ("generalized expectation of achieving the goal"). The second factor included indicators of severity of the emotional component of hope ("perception of the future as "hopelessfulfilled with hopes", "emotional attitude to the future", "emotional state of hope"). In addition, the factor had a negative value of "emotional state of hopelessness".

Based on the structure of each factor and its content, the first factor indicates the existence of a "cognitive-motivational-behavioral gap", the second factor corresponds to the "emotional kind of hope". Thus, we have found two kinds of hope: 1) "an emotional kind of hope"; 2) "rational kind of hope", in the reliable structure of which the cognitive and motivational-behavioral components have a high level of severity. Further analysis of the ratio of the severity of these two types of hope for each participant in the study showed that the "emotional type of hope" predominates significantly. At the same time, 100\% of respondents have a high and medium degree of severity of the state of hope, but $57 \%$ simultaneously have a high level of severity of the state of hopelessness. These data testify to the ambivalent nature of the "emotional kind of hope" in a significant number of study participants. The combination of a state of hope with hopelessness leads to a clash of positive and negative ideas about your life in the future, confidence/uncertainty in achieving desired goals, in direct control of life circumstances, in planning your life for a long time perspective. The ambivalence of experiences due to the combination of the severity of both the state of hope and hopelessness in the "emotional form of hope" lowers 
the desire to overcome difficulties, to transform life (the main positive functions of hope) and reduces the psychological security of a person.

The "rational kind of hope" presented in $20 \%$ of the research participants also does not fully ensure the fulfillment of the positive functions of hope in a person's life. Holders of the "rational type of hope" can find various ways to achieve their goals, move towards them systematically and consciously, but at the same time they doubt their success, feel insecure, etc.

Despite the fact that combination of state of hope and hopelessness is common for "emotional kind of hope ", people with this kind of hope differ from those with the" rational kind of hope", a more positive attitude to the present time $(\mathrm{t}=3.10)$. The future is seen by "representatives of the emotional kind of hope" more saturated with positive events $(\mathrm{t}=$ 5.54) than the past and the present. In other words, "representatives of the emotional kind of hope" demonstrate an optimistic perception of future and believe that it will be better. But if we take into account that cognitive and motivational-behavioral components (passive hope) are insignificantly expressed in the structure of the "emotional type of hope", such an attitude to the future can lead to disappointment, to increased hopelessness, and hence to actualization of negative emotions and to a decrease in the level of psychological security of a person.

"Representatives of the rational type of hope" where the severity of cognitive and motivational-behavioral components prevails, have a more positive attitude to the past than to the present and the future $(t=5.10)$. They worry that they will not be able to fully influence their future, be responsible for the events in their lives. In the process of analyzing the data, we identified a group of research participants who have a negative attitude towards different time stages of their lives. Among them are the participants with a high level of manifestation of hopelessness, and those who have a sufficiently high level of hope. Conditionally, we called the first subgroup "negatively related to life experiencing a state of hopelessness". Representatives of this subgroup not only negatively assess their lives, but also perceive their past, present and future as difficult and devoid of any meaning. They believe that they cannot control the circumstances of their lives, they are sure that everything that happens in their lives is the result of the influence of external factors and not of their own efforts. Representatives of this subgroup are distinguished by a firm conviction that life has brought more disappointments to them than to other people; they believe that life could be happier than it is. The representatives of this subgroup see the future as gloomy, devoid of stability, certainty and the possibility to achieving the goals. 
We defined the second subgroup as "those who have a negative attitude towards life - those who hope." This subgroup of the research participants are distinguished by a low degree of life satisfaction, a negative perception of their life and a high intensity of components of hope. They perceive the present as gloomy, unsafe, boring, eventless and difficult. Looking back at their lives, representatives of this subgroup regret missed opportunities, unfulfilled hopes and unjustified expectations. At the same time, they hope for a future that they see as happier and filled with pleasant events. Representatives of this subgroup are characterized by persistence in achieving goals, the ability to find different ways to achieve their goals, as well as confidence that the productivity of their activities depends mainly on their own dedication.

The data obtained, on the one hand, indicate that the state of hope-hopelessness is associated with the way a person perceives and evaluates his own life. On the other hand, hopelessness is not necessarily the result of dissatisfaction with life and hope is not always associated with a positive, optimistic assessment of life. The combination of a negative attitude to life and hope, which includes not only a pronounced emotional component, but also a cognitive, motivational and behavioral component indicate that hope can "resist" entity, perform the function of transforming entity.

Thus, in the context of the psychology of the security of the individual and society, the appeal to the phenomenon of "hope" turns into an appeal to the "person who hopes", to his experience of hope and the experiences associated with him. Based on the theoretical analysis and the data obtained, it can be concluded that the predominance of the "emotional type of hope", revealed both in the process of studying the ideas about hope and its functions in human life and with the help of psycho-diagnostic and mathematical procedures, leads to a decrease in the psychological security of a person, especially in those cases when a high degree of hopelessness is combined with a negative attitude to life.

Harmonization of all components of hope, development of cognitive and motivational-behavioral components in the structure of hope, actualization of positive functions of hope, specification of ideas about hope and its spheres can become one of the tasks of special social technology that promotes the increase in the psychological security of the individual and society. 


\section{References}

Andrusenko V. A. (1999). Ob'ektivnye osnovaniya nadezhdy (mirovozzrencheskii aspekt) (Objective grounds for hope (ideological aspect) // Vestn. Orenburgsk. gos. univesiteta. № 3 .

Bol'nov, O. F. (2001). Novaya ukrytost'. Problema preodoleniya ekzistencializma. Vvedenie (New hideout. The problem of overcoming existentialism. Introduction) // Filosofskaya mysl'. № 2.

Chalikova, V. A. (1991). Utopiya i utopicheskoe myshlenie (Utopia and utopian thinking). Progress.

Fond "obshestvennoe mnenie". Rossiiskoe obshestvo: cennosti i prioritety // Politicheskie issledovaniya (Public Opinion Foundation. Russian Society: Values and Priorities // Political Studies). (1993), № 6.

Fromm, E. (2005). Revolyuciya nadezhdy. Izbavlenie ot illyuzii (A revolution of hope. Getting rid of illusions). M.

Gorbatkov, A. A. (2003). Issledovanie faktornoi struktury shkaly beznadezhnosti A. Beka (Study of the factor structure of A. Beck's hopelessness scale)// Psihologicheskii vestnik RGU. № 1.

Kamyu, A. (1990). Mif o Sizife. Esse ob absurde (The myth of Sisyphus. Essay on the absurd)// Buntuyushii chelovek. M.

Kapiton, V. P. (1992). Nadezhda (opyt postanovki filosofskoi problemy) (Hope (experience of posing a philosophical problem)) // Osmyslenie duhovnoi celostnosti. Ekaterinburg.

K'erkegor, S. (1993). Strah i trepet (Fear and awe). Moscow.

Kleman, O. (1994). Svideteli nadezhdy v krizisnom mire (Witnesses of Hope in a World of Crisis) // Pravoslavnaya obshina. № 2. (20).

Labunskaya V. A., Mansurova I. S. (2004). Ocenka zhiznennyh sobytii i dispoziciya nadezhdy-beznadezhnosti (Assessment of life events and disposition of hope and hopelessness) // Severo-Kavkazskii psihologicheskii vestnik. № 2 .

Labunskaya, V. A. (2009). Social'no-psihologicheskij podhod k izucheniyu nadezhdy ipredstavleniya o ee funkciyah $v$ zhizni cheloveka (Socio-psychological approach to the study of hope, ideas about its functions in human life) // Social'nye predstavleniya i samoopredelenie molodezhi $v$ izmenyayushchemsya mire. Saratov. 
Mansurova I. S. (2005). K probleme nadezhdy-beznadezhnosti v kontekste zhiznennogo puti lichnosti (Towards the problem of hope / hopelessness in the context of an individual's life path) // Severo-Kavkazskii psihologicheskii vestnik. № 3 .

Mansurova, I. S. (2006). Empiricheskii analiz otnosheniya k nadezhde na razlichnyh zhiznennyh etapah (Empirical analysis of attitudes towards hope at different stages of life) // Izvestiya vysshih uchebnyh zavedenii. SeveroKavkazskii region. "Psihologiya". № 6.

Muzdybaev, K. (1999). Fenomenologiya nadezhdy (The phenomenology of hope)// Psihologicheskii zhurnal. T. 20, №3.

Muzdybaev, K. (1999). Izmerenie nadezhdy (Measuring hope) // Psihologicheskii zhurnal. T. 20. № 4.

Nicshe, F. (1990). Chelovecheskoe, slishkom chelovecheskoe (Human, too human). T. 1. Moscow.

Sartr, Zh. P. (1989). Ekzistencializm - eto gumanizm (Existentialism is Humanism) // Sumerki bogov. M.

Shopengauer A. (1992). Mir kak volya i predstavlenie (The world as will and representation). t. 1. Moscow

Sikevich, Z. V. (1999). "Obraz" proshlogo i nastoyashego v simvolicheskom soznanii rossiyan ("Image" of the past and present in the symbolic consciousness of Russians) // Sociologicheskie issledovaniya. № 1.

Snyder C. R. (1994). Hope and optimism // Encyclopedia of human behavior. SanDiego. V. 2.

Tillih P. (1994). Bytie, nebytie i trevoga (Being, nothingness and anxiety) // Moskovskii psihoterapevticheskii zhurnal. №1.

Vershinin, S. E. (2000). Zhizn' - eto nadezhda. Vvedenie v filosofiyu Ernsta Bloha (Life is hope. Introduction to the philosophy of Ernst Bloch). Ekaterinburg. 